\title{
DISTRIBUSI KEPADATAN IKAN PELAGIS DI PERAIRAN PANTAI UTARA JAWA BAGIAN TIMUR, PULAU-PULAU SUNDA, DAN LAUT FLORES
}

\author{
Asep Priatna1) dan Mohammad Natsir'1) \\ 1) Peneliti pada Balai Riset Perikanan Laut, Muara Baru-Jakarta \\ Teregristrasi I tanggal: 1 Mei 2007; Diterima setelah perbaikan tanggal: 9 Juli 2007; \\ Disetujui terbit tanggal: 7 Agustus 2007
}

\begin{abstract}
ABSTRAK
Penelitian ini bertujuan untuk mempelajari distribusi spasial kepadatan ikan pelagis serta hubungan dengan kondisi perairan pada musim peralihan di perairan pantai utara Jawa bagian timur dan Laut Flores, berdasarkan pada pengambilan contoh akustik dan 34 stasiun oseanografi pada bulan Oktober 2005. Data target strength menunjukkan bahwa rata-rata ukuran ikan pelagis yang terdeteksi di perairan pantai utara Jawa bagian timur adalah 10 sampai dengan $56 \mathrm{~cm}$. Ukuran ikan di daerah lepas pantai lebih kecil dibanding daerah dekat pantai. Pada musim peralihan, kondisi suhu dan salinitas perairan relatif homogen. Sehingga faktor tersebut kurang signifikan terhadap distribusi keberadaan ikan. Diduga faktor lingkungan lain seperti faktor biologi dan kimia, berperan dalam pola penyebaran ikan pelagis kecil di perairan ini. Di Laut Flores dan sekitar Pulau-Pulau Sunda, densitas ikan tertinggi pada stratum 10 sampai dengan $50 \mathrm{~m}$ dengan ukuran 10 sampai dengan $20 \mathrm{~cm}$ terutama di beberapa lahan marginal seperti sekitar selat dan kepulauan. Selain merupakan lapisan tercampur di mana kondisi suhu dan salinitas relatif stabil pada kedalaman 10 sampai dengan $50 \mathrm{~m}$, lahan marginal merupakan daerah subur tempat pertemuan 2 massa air yang berbeda yang membentuk front diharapkan merupakan tempat berkumpul ikan. Lapisan termoklin yang bersifat lemah berada di bawah $50 \mathrm{~m}$, hal ini mempengaruhi densitas ikan yang semakin rendah pada kedalaman lebih dari $50 \mathrm{~m}$. Ikan pelagis yang berada pada lapisan termoklin mempunyai ukuran yang lebih besar yaitu 14 sampai dengan $40 \mathrm{~cm}$. Pada musim yang sama, rata-rata kepadatan dan ukuran ikan pelagis kecil di wilayah timur lebih rendah daripada sebelah barat.
\end{abstract}

KATAKUNCl: ikan pelagis, akustik, densitas, suhu, salinitas

ABSTRACT: The density distribution of pelagic fishes in north of Java coast waters part of East port, Sunda Islands, and Flores Sea. By: Asep Priatna and Mohammad Natsir

The aim of this research is to study the distribution of spasial density of pelagic fish with waters condition at intermonsoon in north of Java coast waters part of east and Flores Sea, based on acoustic sampling and 34 oceanography stations in October 2005. The target strength of fish indicated that pelagic fish measure in north of Java coast waters part of east is about 10 to $56 \mathrm{~cm}$. Fish sizes in offshore is smaller than near shore. At intermonsoon, the waters condition of temperature and salinity was homogeneous relatively. Therefore, that are less to distribution of fish density. Anticipated, the others environmental factor like chemical and biological, was influenced to distribution of small pelagic fish in this area. In Flores Sea and Sunda Islands, the highest of fish density at 10 to $50 \mathrm{~m}$ and fish sizes about 10 to $20 \mathrm{~cm}$ especially in some marginal areas near archipelago and strait. At 10 to $50 \mathrm{~m}$ is mixed layer, where temperature and salinity was relative stabilize, the maginal areas is fertility waters which is passage of the shifting by two different water masses and front were formed. The weak termocline was formed below $50 \mathrm{~m}$, maked fish density are progressively lower below $50 \mathrm{~m}$. The pelagic fish residing in termocline layers have larger ones measure than stratum 10 to $50 \mathrm{~m}$ is about 14 to $40 \mathrm{~cm}$. On same season, the fish measure and density of small pelagic fishes in east region is lower than at westside.

\section{KEYWORDS: $\quad$ pelagic fish, acoustic, density, temperature, salinity}

\section{PENDAHULUAN}

Pengetahuan mengenai penyebaran atau distribusi ikan sangat berguna untuk menjawab beberapa pertanyaan sehubungan dengan pencarian ikan dan pemilihan teknik penangkapan yang sesuai. Pola kehidupan ikan tidak dapat dipisahkan dari ada berbagai kondisi lingkungan perairan dan fluktuasi keadaan lingkungan tersebut. Faktor-faktor lingkungan ini meliputi faktor fisik, kimia, dan biologi lingkungan (Gunarso, 1998). Suhu dan salinitas merupakan parameter fisika yang penting artinya dalam mempelajari kehidupan biota laut, perubahan ke-2 faktor tersebut akan mempengaruhi keadaan 
organisme di suatu perairan (Laevastu \& Hayes, 1981).

Iklim muson merupakan faktor yang menentukan sifat-sifat perairan Laut Jawa. Pertukaran massa air secara musiman dengan Laut Flores menentukan pola penyebaran kelimpahan dan keberadaan ikan pelagis. Kelompok ikan oseanik dan neritik muda memasuki Laut Jawa mengikuti massa air bersalinitas lebih tinggi yang datang dari timur. Sementara itu, kelompok ikan pantai cenderung tinggal di Laut Jawa sepanjang tahun (Sadhotomo \& Durand, 1997).

Untuk mendapatkan hasil pendugaan densitas dan ukuran ikan yang cepat dan relatif akurat, maka penerapan metode akustik diharapkan dapat memberikan hasil yang diinginkan. Dalam tulisan ini, bahasan difokuskan pada hubungan antara faktor lingkungan fisik yaitu suhu dan salinitas terhadap densitas ikan.

\section{BAHAN DAN METODE}

Penelitian dilakukan di pantai utara Jawa bagian timur, sekitar Pulau-Pulau Sunda dan Laut Flores pada bulan Oktober 2005. Kajian dibagi ke dalam 2 sub lahan, sub lahan 1 di pantai utara Jawa bagian timur dengan kedalaman $<100$ m dan sub lahan 2 di sekitar Pulau-Pulau Sunda dan Laut Flores dengan kedalaman $>200 \mathrm{~m}$.

Sarana penelitian adalah K. R. Bawal Putih. Perangkat akustik yang digunakan dalam penelitian ini adalah SIMRAD EK60, yang beroperasi pada

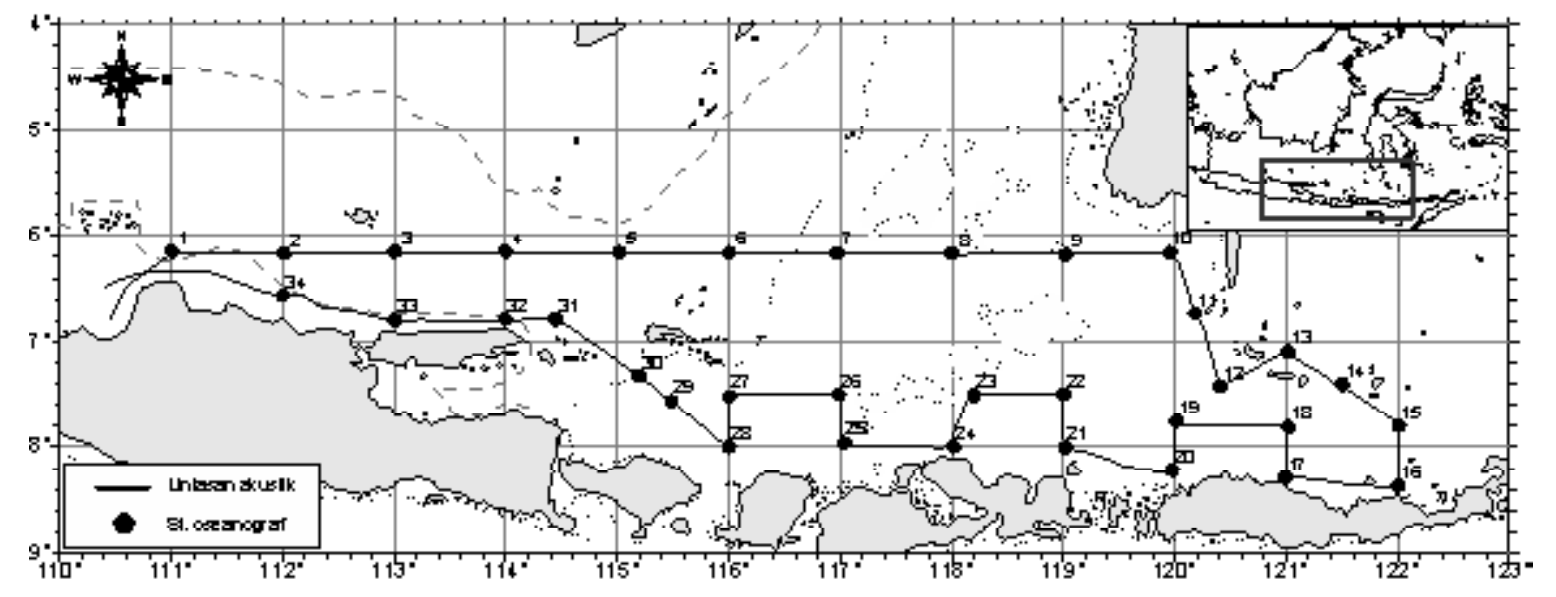

Gambar 1. Lokasi penelitian, desain trek akustik, dan stasiun oseanografi.

Figure 1. Research location, acoustic transect line, and oceanographic stations.

frekuensi $120 \mathrm{KHz}$. Untuk data suhu dan salinitas diambil dengan conductivity temperature and depth sea bird.

\section{Akuisisi Data}

Perekaman data akustik dilakukan pada kolom perairan dengan kedalaman berkisar antara 0 sampai dengan 80 m untuk Laut Jawa dan 0 sampai dengan 150 m untuk Laut Flores. Pengambilan data suhu dan salinitas, yaitu pada titik-titik pengambilan contoh dan disesuaikan dengan kedalaman perairan menghasilkan 34 stasiun oseanografi seperti tampak pada Gambar 1.

\section{Pengolahan dan Analisis Data}

Sasaran ikan yang terdeteksi dikatakan dalam nilai integrator scattering area dalam unit $\mathrm{m}^{2} \mathrm{nmi}^{-2}$ dan sebaran nilai target strength yang menunjukkan variasi dari ukuran ikan dalam unit $\mathrm{dB}$.

Target strength ikan memiliki hubungan yang setara dengan backscattering cross section $\left(\sigma_{b s}\right)$. Menurut persamaan Burczynski \& Johnson (1986) nilai rata-rata tar streng dapat diperoleh dengan:

$$
\overline{\mathrm{TS}}=10 \overline{\log }_{\mathrm{bs}}
$$

Perhitungan densitas ikan menurut MacLennan \& Simmonds (1992):

1. Lahan densitas (fish $\mathrm{nmi}^{-2}$ ):

$\rho A=S A \bar{A} \sigma_{b s}$

2. Volume densitas (fish $1.000 \mathrm{~m}^{-3}$ ) dapat diperoleh:

$\rho V=\rho A(r 2-r 1)$ 
di mana:

$1 \mathrm{nmi} \quad=1.852 \mathrm{~m}$

$\mathrm{r} 1$ dan $\mathrm{r} 2=$ batas strata kedalaman $(\mathrm{m})$

Data akustik disajikan dalam bentuk grafis densitas (garis hitam tebal) dan nilai target strength ikan (garis putus-putus) menurut pembagian strata kedalaman, $10 \mathrm{~m}$ untuk sub lahan 1 dan $50 \mathrm{~m}$ sub lahan 2.

Kondisi suhu dan salinitas ditampilkan dalam bentuk profil menegak pada bagian-bagian yang

Tabel 1.

Pembagian kode transek menurut stasiun oseanografi

Table 1. Group of transect based on oceanography stations

\begin{tabular}{cccc}
\hline No. & Transek/Transect & Stasiun/Station & Sub lahan/Sub land \\
\hline 1. & L1 & $1-6$ & 1 \\
2. & L2 & $30-34$ & 1 \\
3. & L3 & $7-10$ & 2 \\
4. & L4 & $10-15$ & 2 \\
5. & L5 & $15-29$ & 2 \\
\hline
\end{tabular}

melintang serta posisi stasiun yang berdekatan. Analisis meliputi interpretasi visual berbasis pada presentasi grafikal yang merupakan dasar bagi penafsiran data dan penyusunan informasi. Penggambaran penampang vertikal untuk densitas, suhu, dan salinitas dibagi ke dalam 5 transek dengan lintasan membujur ditunjukkan dalam Tabel 1.

\section{HASIL DAN BAHASAN}

\section{Sebaran Kepadatan dan Ukuran Ikan Pelagis di Sub Lahan 1}

Berdasarkan pada hasil yang diperoleh terlihat ada perbedaan konsentrasi dan ukuran ikan pelagis untuk masing-masing lahan dan strata kedalaman yang berbeda.

Hasil menunjukkan bahwa rata-rata ukuran ikan pelagis yang terdeteksi di sub lahan 1 berada pada kisaran -60 sampai dengan $-45 \mathrm{~dB}$. Dengan mengadopsi hubungan panjang ikan sama dengan 20 log TS+konstanta (Foote, 1987), maka ukuran ikan yang terdapat di perairan ini berkisar antara 10 sampai dengan $56 \mathrm{~cm}$.

Kepadatan ikan cukup tinggi terdapat di sebelah barat stasiun 1 atau perairan dangkal sekitar Tanjung Mandalika, dengan densitas rata-rata 300 ekor 1.000 $\mathrm{m}^{-3}$ yang terdiri atas ikan pelagis kecil dengan target strength rata-rata -57 sampai dengan $-54 \mathrm{~dB}$ atau berukuran sekitar 14 sampai dengan $28 \mathrm{~cm}$. Densitas cenderung berkurang di mana diduga berhubungan dengan semakin dangkal kedalaman perairan. Ikan pelagis tersebut diduga merupakan kelompok ikan pantai yang cenderung tinggal di Laut Jawa sepanjang tahun. Sementara itu, hasil penelitian lain menunjukkan bahwa kepadatan di perairan sekitar
Semarang terkadang tinggi karena ada pengaruh musim.

Pada sub lahan 1 terdiri atas transek L1 yang merupakan lahan lepas pantai dan $\mathrm{L} 2$ di dekat pantai. Pada transek L1 (Gambar 2) dengan panjang lintasan sekitar $150 \mathrm{nmi}$, kondisi suhu dan salinitas menunjukkan terjadi stratifikasi horisontal dengan membentuk lapisan isoterm dan isohalin vertikal (Gambar 2). Suhu semakin rendah ke arah timur dan sebaliknya untuk salinitas. Nilai suhu dan salinitas di sebelah barat $29,4^{\circ} \mathrm{C}$ dan $34,3 \mathrm{ppm}$, sedangkan di sebelah timur $28,8^{\circ} \mathrm{C}$ dan $34,9 \mathrm{ppm}$. Tapi perbedaan tersebut sangat kecil dengan gradien suhu hanya $0,005^{\circ} \mathrm{C}$ per nmi dan salinitas $0,004 \mathrm{ppm}$ per nmi. Hal ini, mengindikasikan bahwa kondisi suhu dan salinitas pada L1 adalah mendekati homogen. Diduga pada bulan Oktober yang merupakan waktu musim peralihan dari musim timur ke barat, hanya sedikit atau hampir tidak terjadi pertukaran massa air dari Laut Jawa ke Laut Flores.

Grafik distribusi densitas ikan menunjukkan pola yang sama tiap strata kedalaman. Kepadatan ikan yang tinggi terdapat di antara stasiun 2 sampai dengan 3 , serta di sekitar stasiun 5 pada semua strata kedalaman dengan densitas rata-rata sekitar 400 ekor $1.000 \mathrm{~m}^{-3}$ terdiri atas ikan pelagis kecil dengan target strength rata-rata -60 sampai dengan $-54 \mathrm{~dB}$ berukuran sekitar 10 sampai dengan $20 \mathrm{~cm}$, kepadatan semakin besar dengan bertambah kedalaman. Di antara stasiun 1 sampai dengan 2 terdapat densitas ikan 300 ekor $1.000 \mathrm{~m}^{-3}$ pada strata 30 sampai dengan 50 $m$ dengan struktur ukuran ikan yang hampir sama.

Terdapat beberapa lahan di mana terdeteksi ada ikan yang berukuran lebih besar yaitu $>-51 \mathrm{~dB}$ atau $>28 \mathrm{~cm}$. Berdasarkan pada grafik sebaran densitas 

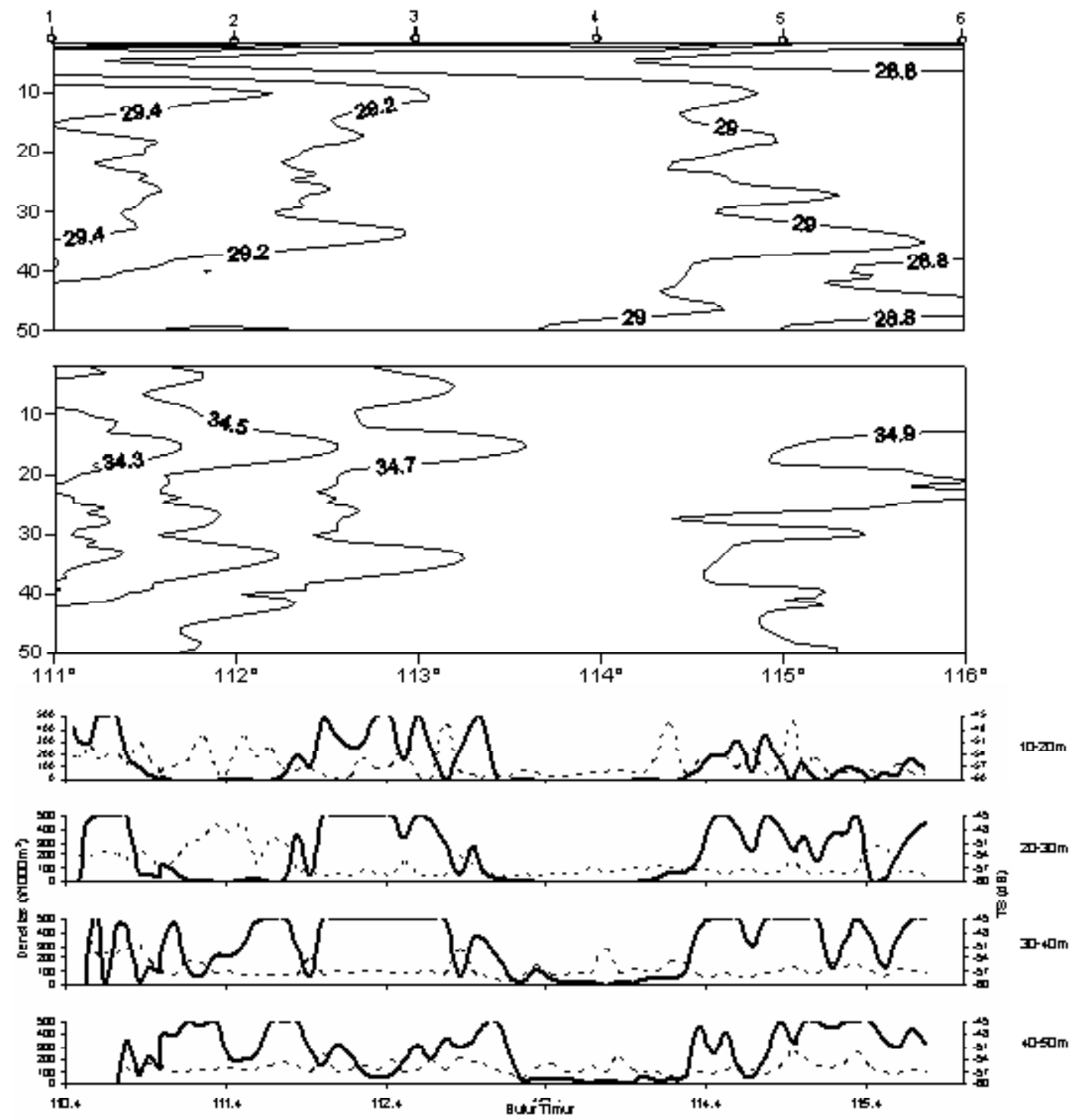

Gambar 2. Penampang tegak longitudinal suhu (atas), salinitas (tengah), kepadatan, dan ukuran ikan (bawah) sepanjang transek 1.

Figure 2. Longitudinal vertical section of temperature (upper), salinity (middle), fish density, and size (lower) along transect 1.

dan ukuran ikan, terdapat kecenderungan bahwa densitas yang rendah dihuni oleh ikan berukuran lebih besar. Hal ini, mengindikasikan bahwa gerombolan ikan pada transek L1 terdiri atas ikan pelagis kecil yang berukuran lebih kecil. Ikan yang berukuran lebih besar cenderung tidak bergerombol atau scatter. Ikan yang berukuran besar tersebut pada umumnya terdapat pada kondisi suhu dan salinitas yang mengalami fluktuasi, walaupun pada perairan L1 fluktuasi sangat kecil. Ikan yang berukuran lebih besar memungkinkan dapat bertahan terhadap perubahan lingkungan yang ditempati.

Pada lahan dekat pantai yaitu transek L2, suhu dan salinitas perairan menunjukkan kondisi yang lebih homogen daripada lahan lepas pantai atau transek L1 dan cenderung menunjukkan stratifikasi vertikal (Gambar 3). Sampai dengan kedalaman 40,5 m suhu di sebelah barat lebih rendah daripada sebelah timur, sementara pada kedalaman $50 \mathrm{~m}$ suhu semakin dingin ke arah timur dengan gradien horisontal $0,0025^{\circ}$ $\mathrm{C}$ per nmi. Sementara itu, isohalin berada pada kondisi homogen dengan nilai salinitas 34,36 ppm. Batas perbedaan suhu dan salinitas secara horisontal terlihat jelas ada di stasiun 31 , di mana stratifikasi vertikal nampak nyata di antara stasiun 30 sampai dengan 31 dengan gradien yang lemah yaitu $0,012^{\circ} \mathrm{C}$ per $\mathrm{m}$ untuk suhu dan 0,004 ppm untuk salinitas. Kondisi perairan di sekitar stasiun 30 sampai dengan 31 mendapat pengaruh dari perairan Laut Flores. 

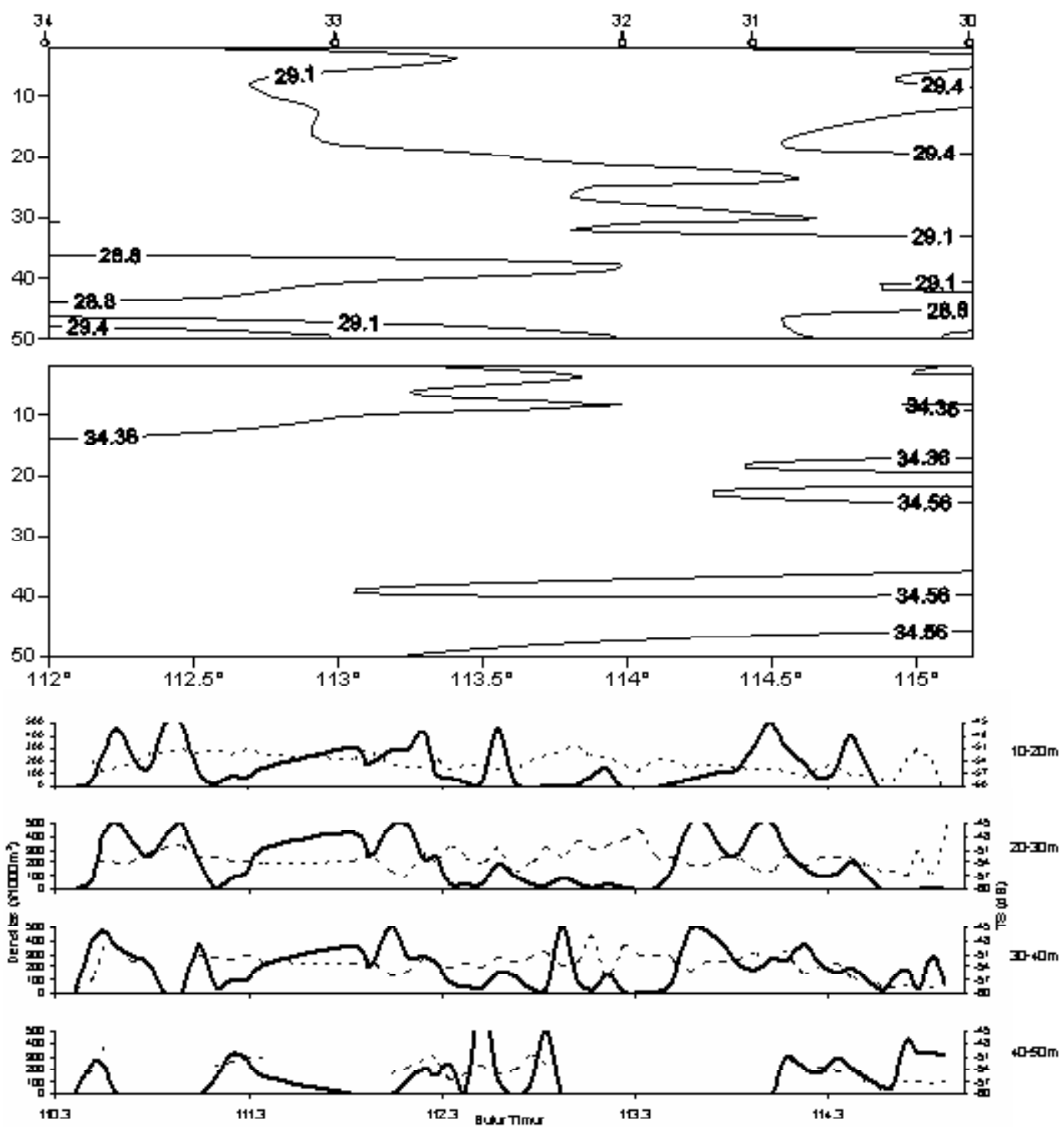

Gambar 3. Penampang tegak longitudinal suhu (atas), salinitas (tengah), kepadatan, dan ukuran ikan (bawah) sepanjang transek 2.

Figure 3. Longitudinal vertical section of temperature (upper), salinity (middle), fish density, and size (lower) along transect 2.

Sebaran densitas ikan menunjukkan pola yang sama pada kedalaman 10 sampai dengan $40 \mathrm{~m}$. Kepadatan ikan terbesar terdapat di sekitar stasiun 32 dan 34 dengan densitas rata-rata 250 ekor 1.000 $\mathrm{m}^{-3}$. Pada strata 30 sampai dengan $50 \mathrm{~m}$, keberadaan sasaran ikan tunggal serta berkurang kepadatan di sebelah barat dan bertambah kepadatan di sebelah timur diduga berhubungan dengan perubahan kedalaman perairan.

Rata-rata nilai target strength yang terdeteksi pada transek L2 -57 sampai dengan $-51 \mathrm{~dB}$ atau berukuran sekitar 14 sampai dengan $28 \mathrm{~cm}$. Ukuran ikan tiap strata kedalaman pada transek L2 cenderung lebih besar dan lebih homogen daripada transek L1.
Seperti halnya pada transek $L 1$, kepadatan yang rendah sekitar stasiun 30 dan di antara stasiun 32 sampai dengan 33 dihuni oleh ikan pelagis yang berukuran lebih besar dibandingkan ikan pelagis lain yang berada dalam densitas tinggi atau bergerombol.

\section{Sebaran Kepadatan dan Ukuran Ikan Pelagis di Sub Lahan 2}

Analisis di perairan Laut Flores (sub lahan 2) terdiri atas 3 transek, transek L3 merupakan jalur pengamatan secara membujur di lahan lepas pantai. Transek L4 tidak sepenuhnya membujur, namun merupakan jalur diagonal dari barat laut menuju tenggara di sekitar kepulauan Selayar dan Kayu Angin. 
Transek L5 adalah trek pararel di bagian selatan Laut Flores. Kondisi suhu dan salinitas di sub lahan 2, jelas menggambarkan stratifikasi vertikal.

Pada transek L3 (Gambar 4), kondisi suhu stratum 10 sampai dengan $50 \mathrm{~m}$ relatif homogen berada pada kisaran isoterm 27 sampai dengan $28^{\circ} \mathrm{C}$ (Gambar 4). Fluktuasi suhu terhadap kedalaman dimulai dari kedalaman $60 \mathrm{~m}$. Pada kedalaman 60 sampai dengan $150 \mathrm{~m}$, suhu semakin hangat ke arah timur dengan gradien horisontal $0,02^{\circ} \mathrm{C}$ per nmi. Gradien vertikal 50 sampai dengan $100 \mathrm{~m} 0,06^{\circ} \mathrm{C}$ per m dan 100 sampai dengan $150 \mathrm{~m} 0,08^{\circ} \mathrm{C}$ per $\mathrm{m}$. Hal tersebut, menunjukkan bahwa lapisan termoklin pada transek L3 bersifat lemah dengan fluktuasi suhu yang sangat kecil yaitu $<0,1^{\circ} \mathrm{C}$ per $\mathrm{m}$. Sementara itu, salinitas menunjukkan kondisi yang homogen dengan isohalin 34,7 sampai dengan 35,1 ppm.

Pada stratum 10 sampai dengan $50 \mathrm{~m}$, kepadatan yang tinggi terdeteksi di sekitar stasiun 7 dengan densitas rata-rata 300 ekor $1.000 \mathrm{~m}^{-3}$ dan di antara stasiun 9 sampai dengan 10 dengan densitas ratarata 200 ekor $1.000 \mathrm{~m}^{-3}$.

Kondisi suhu dan salinitas pada transek L4 (Gambar 5), cenderung sama dengan transek L3 di mana pada stratum 10 sampai dengan $50 \mathrm{~m}$ menunjukkan kondisi homogen dengan isoterm 27 sampai dengan $29^{\circ} \mathrm{C}$ (Gambar 5). Fluktuasi suhu yang kecil pada kedalaman 50 sampai dengan 150 $\mathrm{m}$ mengindikasikan bahwa lapisan termoklin bersifat
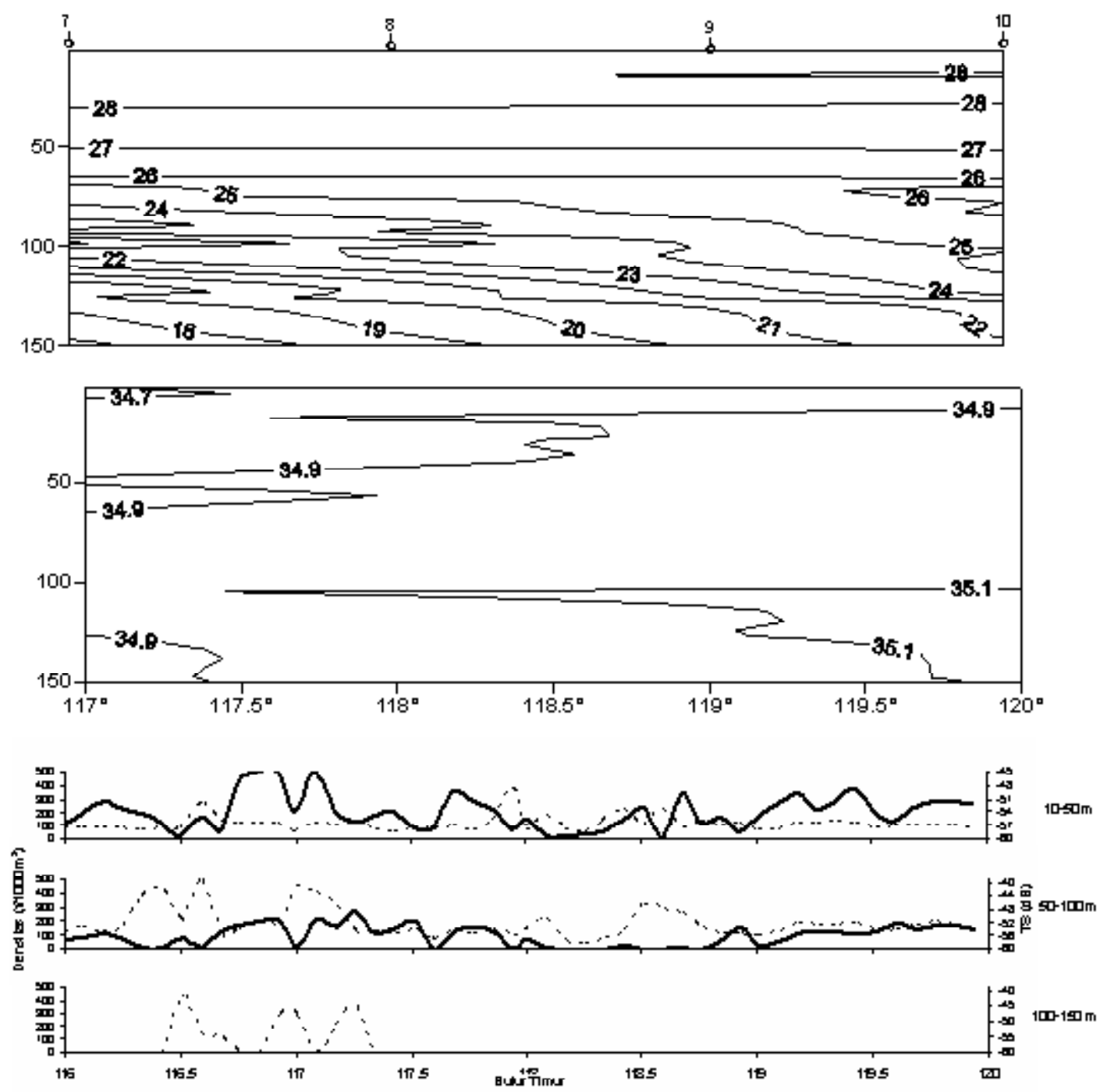

Gambar 4. Penampang tegak longitudinal suhu (atas), salinitas (tengah), kepadatan, dan ukuran ikan (bawah) sepanjang transek 3 .

Figure 4. Longitudinal vertical section of temperature (upper), salinity (middle), fish density, and size (lower) along transect 3. 
lemah dengan gradien suhu yang sama pada transek L3. Salinitas bersifat homogen dengan isohalin 34,9 sampai dengan 35,1 ppm.

Kepadatan ikan pelagis yang tinggi dengan densitas rata-rata mencapai 500 ekor $1.000 \mathrm{~m}^{-3}$ terdapat di antara stasiun 12 sampai dengan 13 yaitu di sekitar gugus Kepulauan Kayu Angin. Daerah ini merupakan lahan marginal, yaitu berupa gugus kepulauan dan terumbu karang sebagai tempat perlindungan dari gerakkan arus dari Laut Banda. Kepadatan terendah di beberapa lahan yaitu $<50$ ekor $1.000 \mathrm{~m}^{-3}$, lebih disebabkan pengaruh arus permukaan dari Laut Banda. Mengingat daerah-daerah tersebut merupakan passage bagi masuk aliran air dari arah timur.
Pada transek L5, kondisi suhu stratum 10 sampai dengan $50 \mathrm{~m}$ relatif homogen berada pada kisaran isoterm 28 sampai dengan 29० C (Gambar 6). Fluktuasi suhu terhadap kedalaman dimulai dari kedalaman $60 \mathrm{~m}$, dengan gradien yang lebih besar daripada termoklin pada transek lain yaitu 0,12 dan $0,08^{\circ} \mathrm{C}$ per $\mathrm{m}$ untuk stratum 50 sampai dengan 100 $\mathrm{m}$ dan 100 sampai dengan $150 \mathrm{~m}$. Mengindikasikan bahwa terdapat lapisan termoklin yang cukup kuat pada kedalaman 50 sampai dengan $100 \mathrm{~m}$. Salinitas bersifat homogen dengan isohalin 34,72 sampai dengan 34,92 ppm.

Pada stratum 10 sampai dengan $50 \mathrm{~m}$, kepadatan ikan yang tinggi terdapat di lahan lepas pantai yaitu di antara stasiun 18 sampai dengan 19 dan stasiun
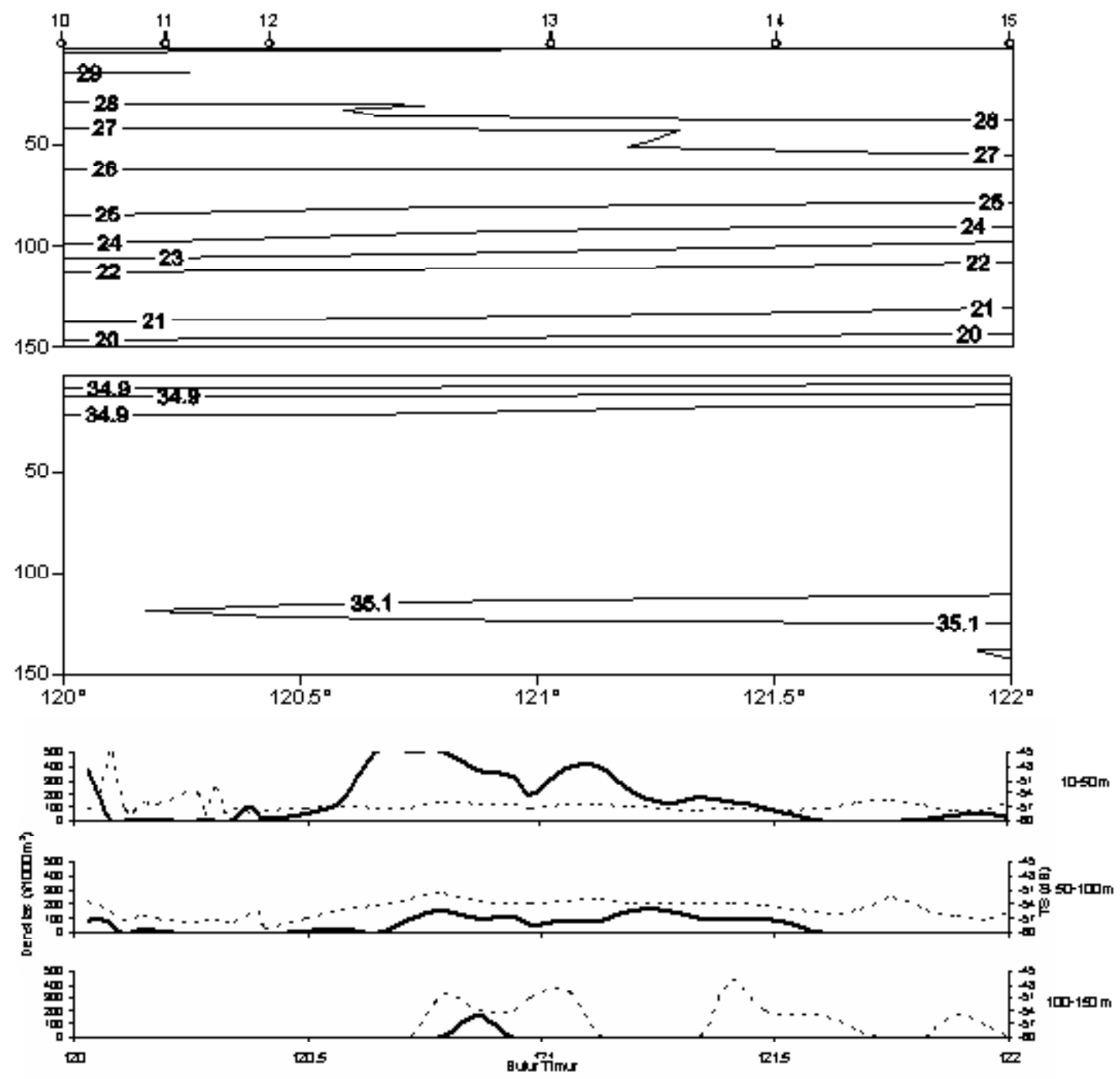

Gambar 5. Penampang tegak longitudinal suhu (atas), salinitas (tengah), kepadatan, dan ukuran ikan (bawah) sepanjang transek 4.

Figure 5. Longitudinal vertical section of temperature (upper), salinity (middle), fish density, and size (lower) along transect 4. 
20 sampai dengan 21 , sedangkan di lahan dekat pantai yaitu di antara stasiun 16 sampai dengan 17, stasiun 24 sampai dengan 25 , serta di sekitar stasiun 28 dengan masing-masing densitas rata-rata 400 ekor $1.000 \mathrm{~m}^{-3}$.

Kepadatan ikan yang tinggi di sekitar stasiun 28 (utara Selat Lombok) karena daerah ini merupakan lahan marginal, yaitu berupa selat sebagai tempat pertemuan 2 massa air dari Samudera Hindia dan Laut Flores yang membentuk front di mana merupakan tempat berkumpul ikan.

Migrasi horisontal diduga terjadi di antara stasiun 20 sampai dengan 21 (utara Selat Sape), di mana di lahan ini yang merupakan lahan marginal kepadatan ikan pelagis kecil sangat rendah yaitu $<50$ ekor 1.000 $\mathrm{m}^{-3}$, kelompok ikan tersebut bermigrasi ke arah utara atau menjauhi pantai.

Pada stratum 10 sampai dengan 50 m, struktur ukuran ikan pelagis kecil mempunyai nilai target strength rata-rata -60 sampai dengan $-54 \mathrm{~dB}$ atau berkisar antara 10 sampai dengan $20 \mathrm{~cm}$.

Di Laut Flores yang terdiri atas transek L3, L4, dan L5. Pada stratum 50 sampai dengan 100 m, lokasi kepadatan ikan pelagis berada pada lokasi yang sama dengan strata 10 sampai dengan 50 m. Namun, kepadatan jauh lebih rendah dari strata di atas, hanya separuh dari kelimpahan pada strata 10 sampai dengan $50 \mathrm{~m}$. Walaupun, pada umumnya lapisan termoklin besifat lemah dengan fluktuasi suhu $<0,1^{\circ}$ $\mathrm{C}$ per $\mathrm{m}$, namun berpengaruh terhadap keberadaan
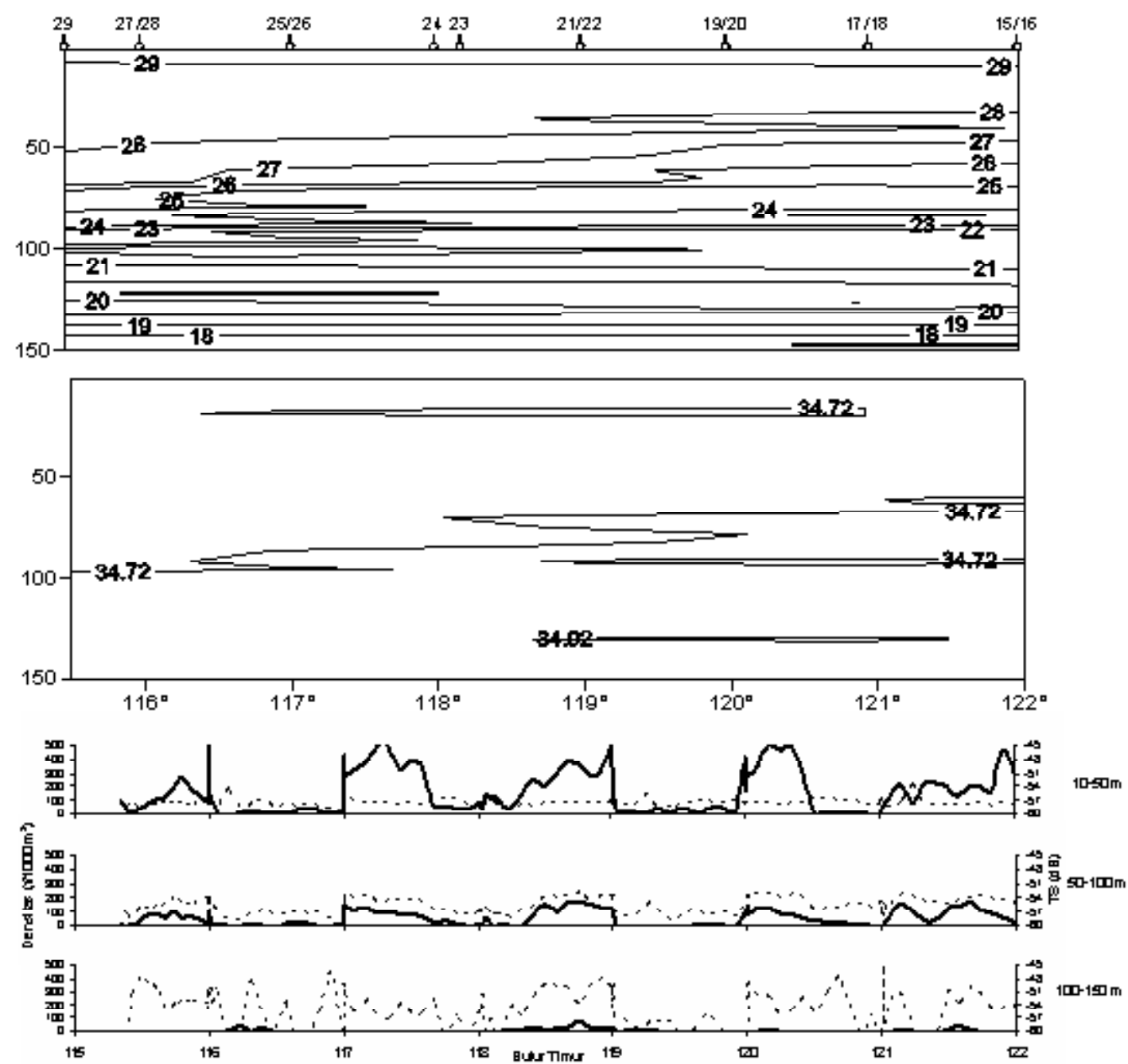

Gambar 6. Penampang tegak longitudinal suhu (atas), salinitas (tengah), kepadatan, dan ukuran ikan (bawah) sepanjang transek 5 .

Figure 6. Longitudinal vertical section of temperature (upper), salinity (middle), fish density, and size (lower) along transect 5. 
organisme. Diduga ikan pelagis cenderung bermigrasi ke permukaan dengan kondisi suhu dan salinitas yang relatif stabil. Pada stratum 50 sampai dengan 100 m ukuran ikan lebih besar daripada stratum 10 sampai dengan $50 \mathrm{~m}$, yaitu berkisar -57 sampai dengan $-48 \mathrm{~dB}$ atau 14 sampai dengan $40 \mathrm{~cm}$. Toleransi yang cukup tinggi terhadap perubahan suhu, memungkinkan jenis-jenis ikan pada ukuran ini mampu beradaptasi pada strata kedalaman ini.

Kepadatan ikan pelagis kecil pada stratum 100 sampai dengan $150 \mathrm{~m}$ rata-rata $<50$ ekor $1.000 \mathrm{~m}^{-3}$, dan hanya terdeteksi di beberapa daerah lepas pantai. Ukuran ikan berkisar 14 sampai dengan $40 \mathrm{~cm}$. Terdeteksi ikan dengan ukuran -42 sampai dengan $36 \mathrm{~dB}$ atau berkisar 80 sampai dengan $150 \mathrm{~cm}$ dengan kepadatan $<50$ ekor $1.000 \mathrm{~m}^{-3}$ yang diduga merupakan ikan pelagis besar, di sekitar stasiun 7 (timur Laut Pulau Kangean) dan sekitar stasiun 18 (utara Pulau Flores) pada $121^{\circ} \mathrm{BT}$ dan $8,2^{\circ} \mathrm{LS}$.

\section{KESIMPULAN}

1. Pada musim peralihan kondisi suhu dan salinitas di perairan Laut Jawa bagian timur relatif homogen, faktor fisik perairan tersebut kurang signifikan terhadap distribusi keberadaan ikan. Diduga faktor lingkungan lain seperti faktor biologi dan kimia, berperan dalam pola penyebaran ikan pelagis kecil di perairan ini. Rata-rata ukuran ikan pelagis di lahan dekat pantai yaitu 14 sampai dengan -28 $\mathrm{cm}$ lebih besar dan cenderung lebih homogen dibandingkan yang jauh dari pantai yaitu 10 sampai dengan $20 \mathrm{~cm}$.

2. Laut Flores pada kedalaman 10 sampai dengan $50 \mathrm{~m}$ merupakan lapisan tercampur dengan suhu dan salinitas cenderung homogen. Lapisan termoklin bersifat lemah terdapat pada kedalaman 50 sampai dengan $150 \mathrm{~m}$ dengan gradien $<0,1^{\circ} \mathrm{C}$ per $\mathrm{m}$. Densitas yang tinggi terdapat di beberapa lahan pada stratum 10 sampai dengan $50 \mathrm{~m}$. Pada stratum 50 sampai dengan $100 \mathrm{~m}$, lokasi kepadatan sama dengan strata di atas, namun densitas jauh lebih rendah. Lapisan termoklin berpengaruh terhadap keberadaan organisme. Rata-rata ukuran ikan pada kedalaman $>50 \mathrm{~m}$ adalah 14 sampai dengan $40 \mathrm{~cm}$, lebih besar daripada ikan di stratum 10 sampai dengan $50 \mathrm{~m}$ yaitu 10 sampai dengan $20 \mathrm{~cm}$.

3. Pada musim yang sama di lapisan permukaan, rata-rata kepadatan dan ukuran ikan pelagis di sub lahan 2 lebih rendah daripada di sub lahan 1. Kecuali di beberapa lahan marginal sekitar selat dan kepulauan terdeteksi ada kepadatan yang cukup besar.

\section{PERSANTUNAN}

Kegiatan dari hasil riset dinamika spasial dan sistem penangkapan di perairan Selat Makassar, Laut Jawa, Laut Cina Selatan, dan perairan Laut Flores, T.A. 2005, di Balai Riset Perikanan Laut-Muara Baru, Jakarta.

\section{DAFTAR PUSTAKA}

Burczyinski, J. J. \& Johnson. 1986. Aplication of dual beam acoustic surveys techniqust limnetic population of Juvenil Sockeys Salmon. Con. Journal Fisheries Aquatic Science. 43 p.

Birowo, S. 1977. Sifat oseanografi permukaan laut. Dalam Kondisi lingkungan pesisir dan Laut Indonesia. Penyunting K. Ronimuhtarto \& S. S. Thoyib. Lembaga Oseanologi Nasional. Lembaga IImu Pengetahuan Indonesia. Jakarta.

Foote, K. G. 1987. Fish target strength for use in echo integration surveys. Journal Acoustic Soc. Am. 82 (3): 981-987.

Gunarso, W. 1998. Tingkah laku ikan dalam hubungannya dengan alat, metode, dan taktik penangkapan. Jurusan Perikanan Sumber Daya Perairan. Fakultas Perikanan. Institut Pertanian Bogor. Bogor.

Johannesson, K. A. \& R. B. Mitson. 1983 Fisheries acoustic a pratical manual for aquatic biomass estimation. FAO. Fisheries Tech. Pop. Roma. 249 p.

Laevastu, T. \& M. L. Hayes. 1981. Fisheries oceanography and ecologi. Fishing New Books Ltd.

Mac Lennan, D. N. \& C. Simmonds. 1992. Fisheries acoustic. Chapman and Hall. London. New York. Tokyo. Melborne. Madras. $325 \mathrm{p}$.

Manurung D. \& D. Simbolon. 1997. Spatial distribution of fish density in relation to environmental factors in Makassar Strait waters. Proceeding of the Acoustics Seminar Akustikan II. Jakarta. 143156.

Nontji, A. 1987. Laut Nusantara. Penerbit Djambatan. Jakarta. 
Petit, D., Cotel P., \& Nugroho D. 1997. Densities and behaviour of pelagic fish population along the Java and Sumatera coast in wet season. Proceeding of the Acoustics Seminar Akustikan II. Jakarta. 91-106.

Petit D., Cotel P., \& Nugroho D. 1997. The seasonal variations of salinity in the Java Sea. Proceeding of the Acoustics Seminar Akustikan II. Jakarta. 29-40.

Sadhotomo, B. \& J. R. Durand. 1997. General feature of Java Sea ecology. Proceeding of the Acoustics Seminar Akustikan II. Jakarta. 43-53.
Sadhotomo, B. \& S. Nurhakim. 2000. Keterkaitan Faktor Oseanografi Dengan Sumber Daya Ikan Pelagis. Bagian I: Deskripsi Faktor Fisik, Abiotik, dan Penyebaran Agregasi Akustik di Laut Flores. Jurnal Penelitian Perikanan Indonesia. Vol.6. No.3. 4. Hal.1-9.

Wyrtki, K. 1961. Physical oceanography of the southeast Asian ater. NAGAReport. Vol.2. Scrippsinst. Oceanography. The University of California. 